\title{
LACTOPEROXIDASE IMMOBILIZED ONTO VARIOUS BEADS FOR PRODUCING NATURAL PRESERVATIVES SOLUTION
}

\author{
A. N. Al-Baarri, M. Ogawa, T. Visalsok, S. Hayakawa
}

ABSTRACT : The natural preservative agent of hypothiocyanite $\left(\mathrm{OSCN}^{-}\right)$has been succeded to determine using immobilized LPO onto various types of beads or matrixes: SP Sepharose Fast Flow (SP-FF), SP Sepharose Big Beads (SP-BB), CNBr activated SP Sepharose (SP-CNBR). Lactoperoxidase (LPO) was obtained from bovine milk. The immobilization method was performed using ion exhange method and adsorption. Immobilized LPO onto matrixes has been stored for 7 days at $4^{\circ} \mathrm{C}$ and $10^{\circ} \mathrm{C}$. Data of the production of $\mathrm{OSCN}^{-}$were collected before and after immobilized LPO storage. Data shows no remarkable effect of the production of $\mathrm{OSCN}^{-}$using immobilized $\mathrm{LPO}$ stored at $4^{\circ} \mathrm{C}$, however, the remarkable reduction has been detected in the production of $\mathrm{OSCN}^{-}$using immobilized LPO that was stored at $10^{\circ} \mathrm{C}$. As a conclusion, the 7 days storage does not change the capability of immobilized LPO for producing OSCN if the immobilized LPO was stored at $4^{\circ} \mathrm{C}$.

Keywords: Lactoperoxidase, immobilization, storage, hypothiocyanite

\section{INTRODUCTION}

LPO in the combination with $\mathrm{SCN}^{-}$and $\mathrm{H}_{2} \mathrm{O}_{2}$, known as LPOs, generates hypothiocyanite $\mathrm{OSCN}^{-}$that kills microorganisms by oxidizing sulphydryl $(-\mathrm{SH})$ groups of microbe's cell membrane proteins (Seifu et al., 2005, Touch et al., 2004, Singh et al., 2009). LPO is a member of the peroxidase family and widely distributed in plants, animals, and human (Kussendrager and Hooijdonk, 2000). Hypothiocyanite produced by LPOs has been shown to be effective against pathogenic bacteria (Borch et al., 1989) as well as non-pathogenic bacteria (Wolfson and Sumner, 1993, Fonteh et al., 2005, Wakabayashi et al., 2007).

Immobilized LPO is a very useful method to efficiently produce hypothiocyanite as a preservatives (Al-Baarri et al., 2010, Al-Baarri et al., 2011). Immobilization provides several significant benefits to enzymes. One is that an enzyme can acquire markedly high thermal and operational stability by virtue of the interaction with immobilization matrix (Altun and Cetinus, 2007, Mahmoud and Helmy, 2009, lyer and Ananthanarayan, 2008). Another is that immobilized enzymes are easily separated from the reaction products and, consequently, reusable (Zhou and Lim, 2009, Tzanov et al., 2002, Choi and Yiu, 2004). These features contribute to reduce the cost of the production of chemical substances using enzyme-catalyzed reactions (Hwang et al., 2004, Altun and Cetinus, 2007). Such an effective biocatalytic reaction (process) using immobilization technology let us challenge the preparation of immobilized LPO.

Enzyme immobilization onto a support matrix is achieved in three different modes: adsorption, cross-linkage and entrapment. In this study, we have attempted the immobilization of LPO on a various support matrixes: SP Sepharose Fast Flow (SP-FF), SP Sepharose Big Beads (SP-

Submitted 9/9/2011, Accepted 20/1/2012. A. N. Al-Baarri is with Animal Agriculture Faculty, Diponegoro University, Semarang 50275, Indonesia. M. Ogawa, S. Hayakawa are with Agriculture Faculty, Kagawa University, Japan. T. Visalsok is with Royal University of Agriculture, Cambodia. Direct inquiries to author A. N. Al-Baarri (Email: omalbari@yahoo.co.id).
$\mathrm{BB}$ ), and $\mathrm{CNBr}$ activated SP Sepharose (SP-CNBR). The immobilized LPO then was used in LPOS reaction for producing $\mathrm{OSCN}^{-}$. The used immobilized LPO then was stored at $4^{\circ} \mathrm{C}$ and $10^{\circ} \mathrm{C}$ for 7 days to explore the feasibility of production of $\mathrm{OSCN}^{-}$.

\section{MATERIALS AND METHODS \\ Materials}

$\mathrm{H}_{2} \mathrm{O}_{2}, \mathrm{KSCN}$, and ABTS as reaction substrate to produce and measure the concentration of hypothiocyanite. Rennet was used to obtain the whey. Sepharose Fast Flow (SP-FF), Sepharose Big Beads (SP-BB) and activated $\mathrm{CNBr}$ Sepharose (SP-CNBr) were used. Fresh cow's milk was provided by a local dairy farm. Unless otherwise specified, all other chemicals were reagent grade.

\section{Purification of LPO}

LPO was purified from whey using method that has been performed by Al-Baarri et al. (2011). The purified LPO (89-102 U/ml) was stored at $-80{ }^{\circ} \mathrm{C}$ until used.

\section{Immobilization procedure}

Three kinds of SP-sepharose, i.e. SP-FF, SP-BB, and SP$\mathrm{CNBr}$ were used as a carrier for LPO immobilization and has been immobilized using procedure of Al-Baarri et. al. (2010). The immobilized LPO then was stored at $4^{\circ} \mathrm{C}$ during 1 week.

Production of $\mathrm{OSCN}^{-}$by immobilized LPO

A hundred milligrams of immobilized LPO was packed in a glass column connected to a feedback tubing with a peristaltic pump. The solution of $0.5 \mathrm{ml}$ of $0.5 \mathrm{mM} \mathrm{KSCN}$ and $0.5 \mathrm{ml}$ of $0.5 \mathrm{mM} \mathrm{H}_{2} \mathrm{O}_{2}$ were added to the column and subsequently circulated through the column using the peristaltic pump. The $\mathrm{OSCN}^{-}$was produced during the circulation of the substrate solution through the column. $\mathrm{OSCN}^{-}$concentration was determined according to the method of Aune and Thomas with minor modifications.

\section{RESULTS AND DISCUSSION}

In this study, LPO immobilized onto matrix was applied to produce $\mathrm{OSCN}^{-}$. Table 1 shows the quantitative 
evaluation of $\mathrm{OSCN}^{-}$produced using immobilized LPO. The LPOs reaction using stored immobilized LPO produced 0.13 , $0.14,0.11, \mathrm{mM} \mathrm{OSCN}^{-}$for SP-FF, SP-BB, and SP-CNBr, respectively. The concentration of $\mathrm{OSCN}^{-}$using no-storageimmobilized LPO produced 0.13, 0.14, $0.12 \mathrm{mM} \mathrm{OSCN}^{-}$for SP-FF, SP-BB, and SP-CNBr, respectively.

Data shows almost no remarkable effect to the storage of immobilized LPO for producing $\mathrm{OSCN}^{-}$. The durability of immobilized LPO within one week of storage is unchanged. These facts imply that the storage of immobilized LPO at $4^{\circ} \mathrm{C}$ results in a storage efficiency of LPO since the immobilized LPO is able to stored with no changes in its capability for $\mathrm{OSCN}^{-}$production.

Tabel 1. Concentration of $\mathrm{OSCN}^{-}$produced from LPOS reaction solution using immobilized LPO that was stored at $4^{\circ} \mathrm{C}$

\begin{tabular}{lll}
\hline \multirow{2}{*}{ Matrix } & \multicolumn{2}{l}{ Concentration of $\mathrm{OSCN}^{-}(\mathrm{mM})$} \\
\cline { 2 - 3 } & No Storage & 7-days Storage \\
\hline SP-FF & 0.13 & 0.13 \\
SP-BB & 0.14 & 0.14 \\
SP-CNBr & 0.12 & 0.11 \\
\hline
\end{tabular}

Tabel 1. Concentration of $\mathrm{OSCN}^{-}$produced from LPOS reaction solution using immobilized LPO that was stored at $10^{\circ} \mathrm{C}$

\begin{tabular}{lll}
\hline \multirow{2}{*}{ Matrix } & \multicolumn{2}{l}{ Concentration of $\mathrm{OSCN}^{-}(\mathrm{mM})$} \\
\cline { 2 - 3 } & No Storage & 7-days Storage \\
\hline SP-FF & 0.13 & 0.11 \\
SP-BB & 0.14 & 0.10 \\
SP-CNBr & 0.12 & 0.08 \\
\hline
\end{tabular}

Our experiment that was showed in Table 2 prompted to the results that storage at $10^{\circ} \mathrm{C}$ easily changes the production of $\mathrm{OSCN}^{-}$using immobilized LPO.

The reduction of the $\mathrm{OSCN}^{-}$production can be explained by the denaturation of LPO during storage (Tamiya et al., 1985). Besides, the presence of natural compounds may induce the reduction of LPO activity. Lactose, as an original compound of bovine whey, has a potent inhibitor for LPO activity (Al-Baarri et al., 2010). Other compound such as casein and amino acid tyrosine might also inhibit LPO activity (Clausen et al., 2008; Fonteh et al., 2005). SCN might also inhibit LPO activity (Reiter and Harnulv, 1984; Singh et al., 2009).

A loss of enzyme activity principally due to the denaturation. The probability of denaturing the protein increases along with the raise of temperature of storage (Chattopadhyay and Mazumdar, 2000; Klibanov, 1979,2001; Nino et al., 2004). This result might become a direct consequence for immobilized LPO to store at $4^{\circ} \mathrm{C}$ in order to maintain the LPO activity.

\section{CONCLUSION}

LPO was able to be adsorbed on SP-FF, SP-BB, and SP$\mathrm{CNBr}$. The LPOs reaction with the immobilized $\mathrm{LPO}$ produced ca. $0.08 \sim 0.15 \mathrm{mM} \mathrm{OSCN}^{-}$solution. The storage of immobilized LPO at $4^{\circ} \mathrm{C}$ resulted in no remarkable effect to the production of hypothiocyanite while the storage at $10^{\circ} \mathrm{C}$ reduced $\mathrm{OSCN}^{-}$production .

\section{REFERENCES}

Al-Baarri, A. N., Ogawa, M. \& Hayakawa, S. 2010. Scale-up studies on immobilization of lactoperoxidase using milk whey for producing antimicrobial agent. Journal of the Indonesian Tropical Animal Agriculture, 35, 185-191.

Al-Baarri, A. N., Ogawa, M. \& Hayakawa, S. 2011. Application of lactoperoxidase system using bovine whey and the effect of storage condition on lactoperoxidase activity. International Journal of Dairy Science, 6, 72-78.

Altun, G. D. \& Cetinus, S. A. 2007. Immobilization of pepsin on chitosan beads. Food Chemistry, 100, 964-971.

Borch, E., Wallentin, C., Rosén, M. \& Björck, L. 1989. Antibacterial effect of the lactoperoxidase/thiocyanate/hydrogen peroxide system against strains of Campylobacter isolated from poultry. Journal of Food Protection, 52, 638641.

Choi, M. M. F. \& Yiu, T. P. 2004. Immobilization of beef liver catalase on eggshell membrane for fabrication of hydrogen peroxide biosensor. Enzyme and Microbial Technology, 34, 41-47.

Fonteh, F. A., Grandison, A. S. \& Lewis, M. J. 2005. Factor affecting lactoperoxidase activity. International Journal of Dairy Technology, 58, 233-236.

Hwang, S., Lee, K.-T., Park, J.-W., Min, B.-R., Haam, S., Ahn, I.-S. \& Jung, J.-K. 2004. Stability analysis of Bacillus stearothermophilus L1 lipase immobilized on surface-modified silica gels. Biochemical Engineering Journal, 17, 85-90.

Iyer, P. V. \& Ananthanarayan, L. 2008. Enzyme stability and stabilization-Aqueous and non-aqueous environment. Process Biochemistry, 43, 1019-1032.

Kussendrager, K. D. \& Hooijdonk, A. C. M. v. 2000. Lactoperoxidase: physico-chemical properties, occurence mechanism of action and application. British Journal of Nutrition, 84, S19-S25.

Mahmoud, D. A. R. \& Helmy, W. A. 2009. Potential Application of Immobilization Technology in Enzyme and Biomass Production (Review Article). Journal of Applied Sciences Research, 5, 2466-2476.

Seifu, E., Buys, E. M. \& Donkin, E. F. 2005. Significance of the lactoperoxidase system in the dairy industry and its potential applications: a review. Trends in Food Science \& Technology, 16, 137-154.

Singh, A. K., Singh, N., Sinha, M., Bhushan, A., Kaur, P., Srinivasan, A., Sharma, S. \& Singh, T. P. 2009. Binding Modes of Aromatic Ligands to Mammalian Heme Peroxidases with Associated Functional Implications. Crystal structures of lactoperoxidase complexes with acetylsalicylic acid, salicylhydroxamic acid, and benzylhydroxamic acid. 
The Journal of Biological Chemistry, 242, 2031120318.

Tamiya, T., Okahashi, N., Sakuma, R., Aoyama, T., Akahane, T. \& Matsumoto, J. J. 1985. Freeze denaturation of enzymes and its prevention with additives. Cryobiology, 22, 446-456.

Touch, V., Hayakawa, S., Yamada, S. \& Kaneko, S. 2004. Effect of lactoperoxidase-thiocyanate-hydrogen peroxide system on Salmonella enteritidis in animal or vegetable foods. International Journal of Food Microbiology, 93, 175-183.

Tzanov, T., Costa, S. A., Gübitz, G. M. \& Cavaco-Paulo, A. 2002. Hydrogen peroxide generation with immobilized glucose oxidase for textile bleaching. Journal of Biotechnology, 93, 87-94.
Wakabayashi, H., Miyauchi, H., Shin, K., Yamauchi, K., Matsumoto, I., Abe, K. \& Takase, M. 2007. Orally Administered Lactoperoxidase Increases Expression of the FK506 Binding Protein 5 Gene in Epithelial Cells of the Small Intestine of Mice: A DNA Microarray Study. Bioscience, Biotechnology, and Biochemistry, 71, 2274-2282.

Wolfson, L. M. \& Sumner, S. S. 1993. Antibacterial activity of the lactoperoxidase system: A Review Journal of Food Protection, 56, 887-892.

Zhou, Y. \& Lim, L.-T. 2009. Activation of Lactoperoxidase System in Milk by Glucose Oxidase Immobilized in Electrospun Polylactide Microfibers. Journal of Food Science, 74, C170-C176. 